(c) American Dairy Science Association, 2004.

\title{
Noncoagulation of Milk in Finnish Ayrshire and Holstein-Friesian Cows and Effect of Herds on Milk Coagulation Ability
}

\author{
A.-M. Tyrisevä, T. Vahlsten, O. Ruottinen, and M. Ojala \\ Department of Animal Science, University of Helsinki, \\ PO Box 28, FIN-00014 Helsinki, Finland
}

\begin{abstract}
The objectives of this study were to compare milk coagulation ability (MCA) and the prevalence of noncoagulation of milk within the main Finnish dairy breeds, Finnish Ayrshire (FA) and Holstein-Friesian (HOL), as well as to study the herd effect on MCA. Data used in the statistical analyses consisted of individual milk samples of $959 \mathrm{FA}, 399 \mathrm{HOL}$, and 50 crossbred cows from 84 herds. Data were collected before the grazing season in the spring 1999. Milk samples were analyzed for the milk coagulation traits (milk renneting time, $R$ and curd firmness, $\mathrm{E}_{30}$ ) and $\mathrm{pH}$. In addition, information on the 305-d milk production traits from the year 1999, and background information about feeding and management regimes of the herds were obtained. Variance components for the random herd and animal effects were estimated using REML methodology and an animal model. Breed, parity, lactation stage (for $\mathrm{R}, \mathrm{E}_{30}$ and $\mathrm{pH}$ only), and a measuring unit (for $\mathrm{R}$ and $\mathrm{E}_{30}$ only) were included as fixed effects in the model. When the effects of concentrate feeding frequency and type of concentrate were studied, the random effect of herd was excluded from the model. A relationship matrix included parents, grandparents, and great grandparents of the cows with observations. The HOL cows were superior to FA cows in MCA when both the proportion of poorly coagulating (PC) and noncoagulating (NC) milk, and the differences in curd firmness were considered. About $30 \%$ of the FA cows and $12 \%$ of the HOL cows produced PC milk. Only $1.3 \%$ of the HOL cows and $8.6 \%$ of the FA cows produced NC milk. Herd effect explained only a minor part of the variation in MCA (8\%) compared with that in 305-d milk production traits (about 43\%). Frequent feeding of the concentrate was associated with good MCA as well as for the high milk, protein and fat yields, but it was not associated with the prevalence of the NC milk.
\end{abstract}

Received November 18, 2003.

Accepted April 19, 2004.

Corresponding author: A.-M. Tyrisevä; e-mail: maria.tyriseva@ animal.helsinki.fi.
(Key words: milk coagulation ability, herd effect, feeding frequency)

Abbreviation key: $\mathbf{C B}=$ crossbred cows, $\mathbf{E}_{\mathbf{3 0}}=$ curd firmness, FA = Finnish Ayrshire, HOL = HolsteinFriesian, $\mathbf{M C A}=$ milk coagulation ability, $\mathbf{N C}=$ noncoagulating milk, $\mathbf{P C}=$ poorly coagulating milk, $\mathbf{R}=$ milk renneting time.

\section{INTRODUCTION}

During the last 15 yr in Finland, consumption of cheese has increased about 50\% (Finnish Food and Drink Industries' Federation, 2003). Thus, the importance of the quality of milk used for cheese production, as well as a need to understand the factors associated with cheese production, have been emphasized.

Casein forms a gel network that entraps fat and other constituents of cheese to form the curd (Green and Grandison, 1993). It can therefore be argued that casein content of milk determines the upper limit of cheese yield. Further, milk coagulation ability (MCA) is an important factor that determines the proportion of the milk that is converted to cheese. Casein content of milk and MCA are thus the crucial factors in cheese production. About $40 \%$ of the variation in MCA and $35 \%$ of the variation in casein content is genetic of origin (Ikonen et al., 2004).

Milk coagulation ability results from a sum of many factors participating in the milk coagulation process. The favorable influence of low $\mathrm{pH}$ of milk and $\kappa$-casein B-allele on MCA has generally been agreed. In addition, the role of calcium in the casein micelle structure and in the milk coagulation process is fundamental (e.g., Brulé et al., 2000; Lenoir et al., 2000). However, based on a recent research of Ikonen et al. (2004), genetic correlations between MCA and casein and between MCA and protein content of milk are negligible in magnitude.

Systematic environmental factors such as lactation stage, parity, and season affect MCA by affecting chemical composition of milk. In addition, herd influences MCA through the management and feeding of the cows, and through the breeds of the cows. Based on the study 
by Ikonen et al. (1999c), MCA of the bulk milks differed considerably between herds. Because individual herd bulk milk may have a detectable effect on a cheese lot, it is important to establish the magnitude of effect of the factors embedded in the herd effects. One of the management factors affecting MCA is the udder health of the cows. Mastitis has a very detrimental effect on MCA and cheese quality (e.g., Bergère and Lenoir, 2000). Further, a moderate, unfavorable genetic correlation exists between MCA and SCC (Ikonen et al., 2004). The energy level of cows' diets has been quite clearly associated with MCA (e.g., Macheboeuf et al., 1993; Malossini et al., 1996).

The breed differences in MCA and in the quality of cheese are likely to be based on the differences in milk protein genotypes and chemical composition of milk. It seems possible that noncoagulation of milk (NC), i.e., milk forms no curd after the addition of rennet within the 30-min testing time, is associated with breed as well. Noncoagulating milk is very poor raw material for cheese production. It is a common problem in the Finnish Ayrshire (FA) population. About $13 \%$ of the FA cows produced NC milk in a sample of 4700 cows (Ikonen et al., 2004). So far it has not been detected in the Holstein-Friesian (HOL) in Finland (Ikonen, 2000), and there is only one reported case in Finncattle (Tervala et al., 1985). However, the sample sizes have been small in both breeds.

In Estonia, about $8 \%$ of the milk samples from the Estonian Holstein, Red-and-White Holstein, Estonian Red, and Estonian Native breeds were NC, Red-andWhite Holstein being the poorest with the prevalence of $11 \%$ NC milk (Kübarsepp et al., 2003). In addition, there are reports of cows producing NC milk in the Italian Holstein-Friesian and Friesian populations with the prevalence of about 8\% (Zannoni et al., 1981; Mariani et al., 1982; Malossini et al., 1996). Further, $38 \%$ of the Canadian Holstein cows in one herd produced NC milk at the very end of lactation (Okigbo et al., 1985a, 1985b). There are also some reported cases in the Italian Brown breed (Malossini et al., 1996).

The causes of NC milk have not been fully established. Based on the Finnish studies, it seems to be caused largely by genetic factors in the FA: a wide variation (0 to 50\%) exists in the proportion of $\mathrm{NC}$ daughters between sires (Ikonen et al., 1999a, 2004). In addition, the estimate of heritability for curd firmness as a binary trait (coagulated and noncoagulated samples) was quite high, 0.26 , indicating a genetic predisposition to the phenomenon (Ikonen et al., 2004). Further, none of the environmental factors can thoroughly explain NC milk, even though it has been reported that $\mathrm{pH}$ and SCC of milk, calcium content of milk, and lactation stage are somehow associated with NC (Okigbo et al., 1985a, 1985b; Mariani et al., 1993; Sala et al., 1993; Tyrisevä et al., 2003; Ikonen et al., 2004).

The objectives of this study were to estimate the breed differences between the main Finnish dairy breeds, Finnish Ayrshire, and Holstein-Friesian, in milk coagulation ability and the prevalence of $\mathrm{NC}$ milk. Another aim was to study the herd effect and the effects of concentrate feeding frequency and type of concentrate on MCA.

\section{MATERIAL AND METHODS}

\section{Collection of Milk Samples}

Milk samples utilized in this study were provided as a part of the development project of a cooperative dairy located in central Finland. Aims of the project were to study the variation of MCA of the cows in the region of the cooperative dairy, the factors affecting MCA, and to provide the dairy farmers information on how to improve the quality of milk for cheese production. About $90 \%$ of the herds in the region participated in the sampling. Milk samples on 1802 cows from 125 herds were collected before the grazing season in April and May 1999. Individual milk samples from the evening and the following morning milkings were collected with a milk yield meter and were combined into a sample tube with a preservative (Bronopol, Knoll Pharmaceuticals, Nottingham, UK), stored in the refrigerator and transported at about $4^{\circ} \mathrm{C}$ to the Department of Animal Science, University of Helsinki. Milk samples were on average $2 \mathrm{~d}$ old when analyzed for the milk coagulation ability and $\mathrm{pH}$.

\section{Laboratory Analyses}

Milk (10 mL) was heated to $35^{\circ} \mathrm{C}$, and $200 \mu \mathrm{L}$ of rennet (Hansen standard 190 with $63 \%$ of chymosin and $37 \%$ of pepsin), diluted 3:100 with sodium acetate buffer, was added before renneting. Milk renneting time $(\mathrm{R}, \mathrm{min})$ and curd firmness $\left(\mathrm{E}_{30}, \mathrm{~min}\right)$ were measured with Computerized Renneting Meter, CRM (Polo Trade, Italy) for $31 \mathrm{~min}$. Milk renneting time is the time from the addition of rennet to the beginning of coagulation, and curd firmness is the width of the curd 31 min after the addition of rennet (Ikonen et al., 2004). In addition, the $\mathrm{pH}$ of the milk samples was measured with $744 \mathrm{pH}$ meter (Metrohm, Switzerland).

\section{Data Used in Statistical Analyses}

Cows in the herds that did not belong to the Finnish milk recording system were excluded from the statistical analyses. In addition, cows with milk samples obtained 1 to $5 \mathrm{~d}$ after calving or with missing or incorrect 
information, and 15 Finncattle cows were excluded from the analyses. Consequently, the data used for the statistical analyses consisted of 1408 cows from 84 herds. Of the cows, 959 were FA, $399 \mathrm{HOL}$, and 50 crossbred (CB) animals. Of the CB cows, 22 were crossbreds of FA and HOL, and 28 had either a FA or a HOL dam or sire and an unknown second parent. The size of the herds ranged from 4 to 36 with a mean of 17 cows. About $45 \%$ of FA cows and $58 \%$ of HOL cows were in the mixed herds $(\mathrm{FA}+\mathrm{HOL}, \mathrm{FA}+\mathrm{HOL}+\mathrm{CB}, \mathrm{FA}+$ $\mathrm{CB}$, or $\mathrm{HOL}+\mathrm{CB}$ ).

Cows in the data were daughters of $371 \mathrm{FA}$ and 176 HOL bulls. The number of daughters for a sire ranged from 1 to 33 in the FA bulls with a mean of 2.6 daughters, and from 1 to 24 in the HOL bulls with a mean of 2.4 daughters. About 59\% of the FA bulls and 54\% of the HOL bulls had only one daughter.

Information on birth dates, calving dates, 305-d milk production traits from the year 1999, and pedigree information for the cows were obtained from the Agricultural Data Processing Centre of Finland. In addition, the farmers provided information on feeding and management of the herds by filling out questionnaires.

\section{Statistical Analyses}

The effects of breed, parity, and stage of lactation on $\mathrm{R}, \mathrm{E}_{30}$, milk $\mathrm{pH}, 305$-d milk, fat, and protein yields, and protein and fat content, and the variance components of the random animal, herd, and residual effects, were analyzed with the following univariate linear mixed model:

$$
\begin{gathered}
\mathrm{y}_{\mathrm{ijklmn}}=\mu+\text { Breed }_{\mathrm{i}}+\text { Par }_{\mathrm{j}}+\text { Lact }_{\mathrm{k}}+ \\
\text { Unit }_{\mathrm{l}}+\mathrm{c}_{\mathrm{m}}+\mathrm{a}_{\mathrm{n}}+\varepsilon_{\mathrm{ijklmn}},
\end{gathered}
$$

where

$$
\begin{aligned}
& \mathrm{y}_{\mathrm{ijk} \mathrm{km}}=\mathrm{a} \text { trait studied, } \\
& \mu=\text { an overall mean, }
\end{aligned}
$$

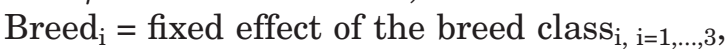

$$
\begin{aligned}
& \operatorname{Par}_{j}=\text { fixed effect of the parity } \operatorname{class}_{j}, j=1, \ldots, 4 \text {, } \\
& \text { Lact }_{\mathrm{k}}=\text { fixed effect of the lactation stage class } \mathrm{k}, \mathrm{k}= \\
& 1, \ldots, 11 \text { (for the traits } \mathrm{R}, \mathrm{E}_{30} \text { and } \mathrm{pH} \text { only), } \\
& \text { Unit }_{1}=\text { fixed effect of the measuring } \text { unit }_{1, l=1, \ldots, 20} \text { in } \\
& \text { the two CRM devices (for the traits } \mathrm{R} \text { and } \\
& \mathrm{E}_{30} \text { only), } \\
& \mathbf{c}_{\mathrm{m}}=\text { random effect of a herd } m, \mathrm{~N}\left(\mathbf{0}, \mathbf{I} \sigma_{\mathrm{c}}^{2}\right) \text {, } \\
& \mathrm{a}_{\mathrm{n}}=\text { random additive genetic effect of an animal } \\
& n, \mathrm{~N}\left(\mathbf{0}, \mathbf{A} \sigma_{\mathrm{a}}^{2}\right) \text {, and } \\
& \varepsilon_{\mathrm{ijklmn}}=\text { random residual effect, } \mathrm{N}\left(\mathbf{0}, \mathbf{I} \sigma_{\varepsilon}^{2}\right) \text {. }
\end{aligned}
$$

Breed effect included 3 classes: FA, HOL, and CB. Cows in the data had calved 1 to 11 times, and parity was grouped into 4 classes: $1,2,3$, and $\geq 4$ parities. Lactation stage was grouped into 11 classes of 1-mo intervals, except for the last class, which included cows with 301 to $534 \mathrm{~d}$ after calving. Both of the $2 \mathrm{CRM}$ devices included 10 measuring units and each unit was treated as a separate class.

Estimation of the variance components was based on REML methodology and an animal model. Pedigree information included parents, grandparents, and great grandparents of the 1408 cows with observations. The total number of the animals in the relationship matrix was 4709 .

Covariances between the effects of $c, a$, and $\varepsilon$ were assumed to be zero. Heritabilities were calculated using the formula $\mathrm{h}^{2}=\sigma_{\mathrm{a}}^{2} /\left(\sigma_{\mathrm{a}}^{2}+\sigma_{\mathrm{c}}^{2}+\sigma_{\varepsilon}^{2}\right)$, and herd effects using the formula $\mathrm{c}^{2}=\sigma_{\mathrm{c}}^{2} /\left(\sigma_{\mathrm{a}}^{2}+\sigma_{\mathrm{c}}^{2}+\sigma_{\varepsilon}^{2}\right)$.

Variance components for the random effects were computed by the REML VCE 4.0-software (Groeneveld, 1997). Solutions for the fixed effects were obtained by the PEST-software (Groeneveld, 1990), and the statistical significance of the fixed effects was tested by the $F$ test of the PEST software (Groeneveld, 1990).

To study the effects of some separate herd factors on the traits studied, the random herd effect was excluded from the model, and it was replaced by the 2 feeding factors, concentrate feeding frequency, and type of concentrate. For the model with the 2 feeding factors, the number of the cows with observations dropped to 1260 and the total number of the animals in the relationship matrix was 4292 . Otherwise the model was the same as described above. Concentrate feeding frequency was grouped into 4 classes: $2,3,4$, and $\geq 5$ times per day. Type of concentrate was grouped into 6 classes: farm mixture (composed of barley and oats in Finland) with 1 to $52 \%$ oats, farm mixture with 53 to $75 \%$ oats, farm mixture with 76 to $100 \%$ oats, compound feed, the combination of compound feed and farm mixture with 1 to $60 \%$ oats in the farm mixture, and the combination of compound feed and farm mixture with 61 to $100 \%$ oats in the farm mixture.

\section{RESULTS}

\section{Variation in the Traits Studied}

Coefficients of variation were much larger in milk coagulation traits than in 305-d milk production traits (Table 1). The frequency distribution for curd firmness skewed to the left and was slightly bimodal for FA cows (Figure 1). A clear difference existed in MCA between FA and HOL cows (Figure 1). About $30 \%$ of the FA cows, and only $12 \%$ of the HOL cows produced poorly coagulating milk (PC), i.e., curd firmness does not reach a value of $20 \mathrm{~mm}$ in $30 \mathrm{~min}$ (Figure 1 ). The value $<20 \mathrm{~mm}$ 
Table 1. Means and variation of the milk renneting time (R), curd firmness $\left(\mathrm{E}_{30}\right), \mathrm{pH}$ and 305-d milk production traits.

\begin{tabular}{llccr}
\hline Variable & $\mathrm{n}$ & Mean & $\mathrm{SD}$ & CV\% \\
\hline $\mathrm{R}, \mathrm{min}$ & 1319 & 11.2 & 5.0 & 45 \\
$\mathrm{E}_{30}, \mathrm{~mm}$ & 1408 & 26.5 & 11.8 & 45 \\
$\mathrm{pH}$ & 1407 & 6.65 & 0.08 & 1 \\
Milk yield, kg & 1264 & 7377 & 1581 & 21 \\
Fat yield, kg & 1264 & 318 & 70 & 22 \\
Fat, \% & 1264 & 4.35 & 0.62 & 14 \\
Protein yield, kg & 1264 & 241 & 51 & 21 \\
Protein, \% & 1264 & 3.27 & 0.22 & 7 \\
\hline
\end{tabular}

indicates that the curd is not firm enough for cutting in normal time in cheese production. A total of $8.6 \%$ of the FA cows produced NC milk, i.e., milk that obtains no value for renneting time, and the value for curd firmness is $0.0 \mathrm{~mm}$ (Figure 1). In HOL, the prevalence of NC milk was $1.3 \%$. The majority of the FA cows producing $\mathrm{NC}$ milk were descendants of widely used FA and Norwegian Red Breed ancestors both from the sire and dam lines. The proportion of daughters producing $\mathrm{NC}$ milk within $21 \mathrm{FA}$ bulls with $\geq 10$ daughters ranged from 0 to $29 \%$. The $5 \mathrm{HOL}$ cows producing NC milk shared 2 common ancestors, both foreign bulls, in grandparent or great grandparent generations. In addition, 2 of the sires of the NC cows were full sibs.

\section{Effect of Breed}

On average, milk started to aggregate 2.4 min earlier and was $4.1 \mathrm{~mm}$ firmer in HOL cows than in FA cows (Table 2). Further, pH of milk was lower and 305-d milk and protein yields were higher for HOL cows than for FA cows. However, FA cows were superior to HOL cows in fat and protein content (Tables 2 and 3).

\section{Effects of Lactation Stage and Parity}

Stage of lactation had a strong effect on milk renneting time, curd firmness, and $\mathrm{pH}$ of milk $(P<0.001$,

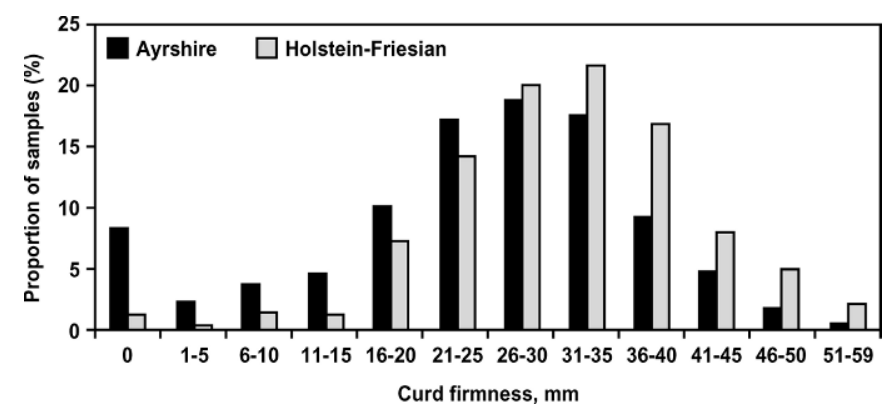

Figure 1. Distribution of the milk coagulation ability (curd firmness, mm) of the Finnish Ayrshire and Holstein-Friesian cows. Zero on the horizontal axis refers to the noncoagulating milk samples. The higher the value for curd firmness, the better the milk is for cheese production.
Table 4). Milk coagulation ability was best at the very beginning and at the end of lactation. At the end of lactation MCA did not, however, reach the level of the early lactation. In FA, the proportion of NC milk samples was not associated with the lactation stage, but in HOL cows, all the NC samples were in the late lactation. The $\mathrm{pH}$ of milk was lowest at the very beginning of the lactation, increased steeply until the second month, and then increased steadily to the end of lactation.

Parity had no statistically significant effect on MCA or on fat content. The $\mathrm{pH}$ of milk deteriorated, 305$\mathrm{d}$ milk, fat, and protein yields increased, and protein content decreased with parity $(P<0.001)$. The 4 parity classes did not differ in the proportion of $\mathrm{NC}$ milk samples.

\section{Effect of Herd}

Estimates of herd effects. Compared to 305-d milk production traits, herd explained only a minor part of the variation in MCA and $\mathrm{pH}$ of milk (average $43 \%$ vs. 9\%, Table 5).

Concentrate feeding frequency. Feeding of concentrate only twice a day had a slightly unfavorable effect on MCA and $\mathrm{pH}$, compared with the cows fed concentrate more frequently (Table 2). Feeding frequency had no effect on the proportion of NC milk samples, but the production of PC milk was $10 \%$ units more common for the cows fed only twice a day than for the other cows.

Feeding of concentrate only twice a day had a very detrimental effect on 305-d milk, fat, and protein yields. Cows fed twice a day produced about $1000 \mathrm{~kg}$ less milk, $25 \mathrm{~kg}$ less fat, and $30 \mathrm{~kg}$ less protein in a year compared with the cows fed 4 times a day with concentrate. Feeding frequency had no clear effect on protein content, but fat content decreased linearly along the feeding frequencies (Table 3).

Type of concentrate. Farm mixture with a moderate amount of oats had a small favorable effect on curd firmness (Table 2). Type of concentrate had, however, no effect on the proportion of $\mathrm{NC}$ and PC milk. The higher the proportion of oats in farm mixture, the lower the 305 -d milk, fat, and protein yields. The combination of farm mixture and compound feed were associated with the best 305-d milk, fat, and protein yields (Table 3).

Comparison of herds. To further study the herd effect, herds were divided into the 10 highest and 10 lowest based on their 305-d protein yields (Table 6), and the raw means of the various traits were compared. There were more than 2 phenotypic SD units difference in the mean 305-d milk and protein yields and more than one phenotypic SD units difference in the mean 305-d fat yield, but no difference in curd firmness be- 
Table 2. Estimates ( \pm SE) of the breed effects, concentrate feeding frequency, and type of concentrate on milk coagulation traits ${ }^{1}$ and $\mathrm{pH}$. A value under the trait name is a raw mean of the trait. Zero refers to the class of comparison.

\begin{tabular}{|c|c|c|c|c|c|c|c|}
\hline \multicolumn{2}{|l|}{ Fixed effect } & $\mathrm{n}$ & $\begin{array}{l}\mathrm{R}, \min \\
\overline{\mathrm{x}}=11.2\end{array}$ & $\mathrm{n}$ & $\begin{array}{l}\mathrm{E}_{30}, \mathrm{~mm} \\
\overline{\mathrm{x}}=26.5\end{array}$ & $\mathrm{n}$ & $\begin{array}{l}\mathrm{pH} \\
\bar{x}=6.65\end{array}$ \\
\hline \multicolumn{2}{|l|}{ Breed $^{2}$} & 1319 & & 1408 & & 1407 & \\
\hline \multicolumn{2}{|l|}{ FA } & 877 & 0 & 959 & 0 & 959 & 0 \\
\hline \multicolumn{2}{|l|}{ HOL } & 394 & $2.4 \pm 0.5$ & 399 & $4.1 \pm 1.2$ & 398 & $-0.016 \pm 0.008$ \\
\hline \multicolumn{2}{|l|}{ Crossbred } & 48 & $0.6 \pm 0.8$ & 50 & $0.7 \pm 1.7$ & 50 & $-0.006 \pm 0.011$ \\
\hline \multicolumn{2}{|c|}{$P$-value } & & $<0.001$ & & 0.002 & & 0.104 \\
\hline \multicolumn{2}{|c|}{ Feeding of concentrate (times/d) } & 1178 & & 1260 & & 1259 & \\
\hline \multicolumn{2}{|c|}{2} & 282 & $0.8 \pm 0.4$ & 306 & $-2.3 \pm 0.9$ & 306 & $0.010 \pm 0.006$ \\
\hline \multicolumn{2}{|l|}{3} & 140 & $-0.1 \pm 0.5$ & 150 & $-0.3 \pm 1.1$ & 150 & $-0.002 \pm 0.007$ \\
\hline \multicolumn{2}{|l|}{4} & 411 & 0 & 438 & 0 & 438 & 0 \\
\hline \multicolumn{2}{|l|}{$\geq 5$} & 345 & $\begin{array}{l}0.0 \pm 0.04 \\
0.151\end{array}$ & 366 & $\begin{array}{r}-0.5 \pm 0.9 \\
0.044\end{array}$ & 365 & $\begin{array}{r}-0.006 \pm 0.006 \\
0.063\end{array}$ \\
\hline \multirow{4}{*}{$\begin{array}{l}\text { Concentrate } \\
\text { Farm mixture: }\end{array}$} & Oats- $\%$ & 1178 & & 1260 & & 1259 & \\
\hline & $1-52$ & 271 & 0 & 289 & 0 & 289 & 0 \\
\hline & $53-75$ & 240 & $-0.4 \pm 0.4$ & 250 & $1.2 \pm 1.0$ & 250 & $-0.021 \pm 0.006$ \\
\hline & $76-100$ & 236 & $0.5 \pm 0.4$ & 255 & $-1.9 \pm 0.9$ & 254 & $-0.007 \pm 0.006$ \\
\hline \multirow{3}{*}{$\begin{array}{l}\text { Compound feed: } \\
\text { Combination: }\end{array}$} & 0 & 69 & $-0.4 \pm 0.7$ & 72 & $-1.9 \pm 1.5$ & 72 & $-0.013 \pm 0.010$ \\
\hline & $1-60$ & 136 & $0.8 \pm 0.5$ & 145 & $-2.4 \pm 1.1$ & 145 & $0.003 \pm 0.007$ \\
\hline \multirow{2}{*}{\multicolumn{2}{|c|}{$P$-value }} & 226 & $-0.0 \pm 0.5$ & 249 & $-0.8 \pm 1.0$ & 249 & $-0.007 \pm 0.006$ \\
\hline & & & 0.151 & & 0.007 & & 0.010 \\
\hline
\end{tabular}

${ }^{1}$ Milk coagulation traits: $\mathrm{R}=$ milk renneting time $(\mathrm{min}), \mathrm{E}_{30}=$ curd firmness $(\mathrm{mm})$.

${ }^{2} \mathrm{FA}=$ Finnish Ayrshire, HOL = Holstein-Friesian.

tween the highest and the lowest herds. The proportion of NC milk samples did not differ between the herd groups. However, in the lowest producing herds, the proportion of PC milk was 18 percentage units higher than in the highest herds. The highest producing herds had more cows, but fewer crossbred animals than the lowest herds. Further, in the highest producing herds cows were fed several times a day, and concentrate was more often the combination of farm mixture and compound feed, and the proportion of oats was lower in farm mixture than in the lowest producing.

\section{Estimates of Heritability}

Although our data was somewhat limited for estimating heritabilities, standard errors were reasonably small in magnitude. Estimates of heritability for the milk coagulation traits were of the same magnitude

Table 3. Estimates $( \pm$ SE) of the breed effects, concentrate feeding frequency, and type of concentrate on 305-d milk production traits. A value under the trait name is a raw mean of the trait. Zero refers to the class of comparison.

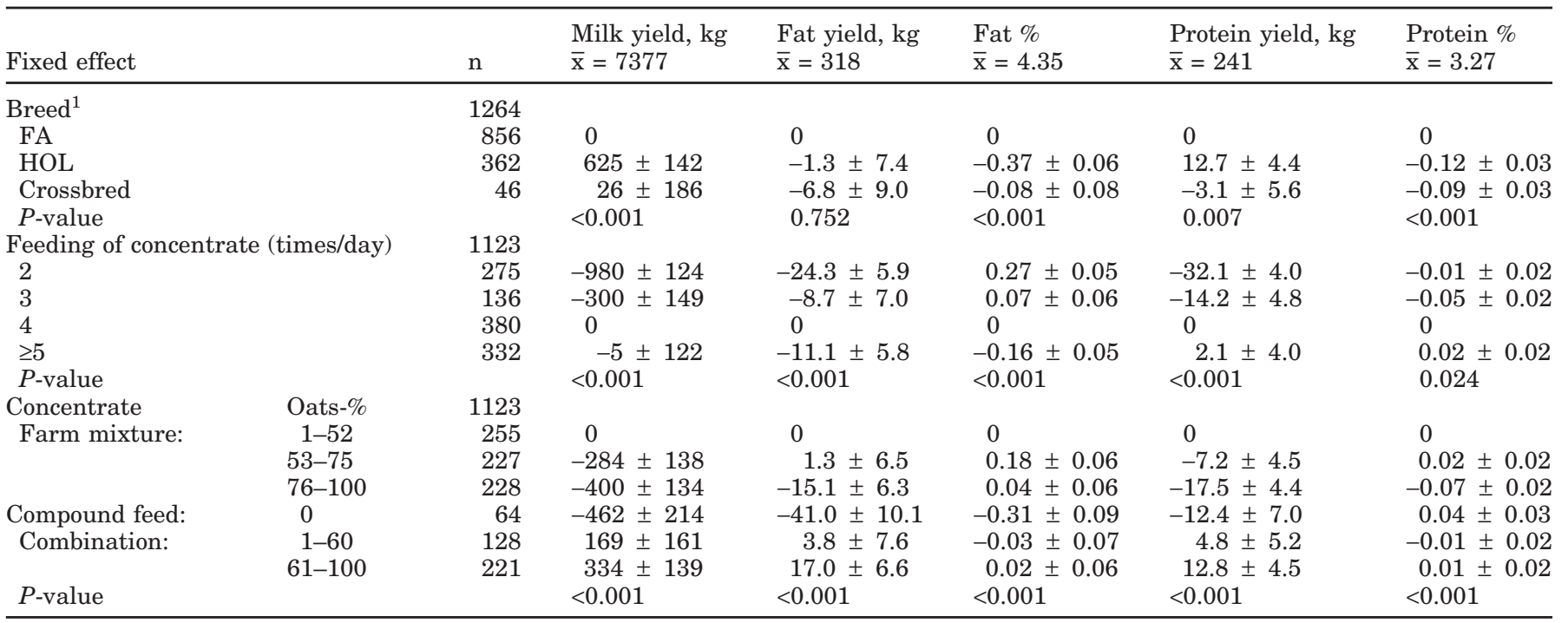

\footnotetext{
${ }^{1} \mathrm{FA}=$ Finnish Ayrshire, HOL = Holstein-Friesian.
} 
Table 4. Estimates ( \pm SE) of the effect of lactation stage on milk coagulation traits ${ }^{1}$ and $\mathrm{pH}$. A value under the trait name is a raw mean of the trait. Zero refers to the class of comparison.

\begin{tabular}{|c|c|c|c|c|c|c|}
\hline $\begin{array}{l}\text { Lactation } \\
\text { stage }\end{array}$ & $\mathrm{n}$ & $\begin{array}{l}\mathrm{R}, \min \\
\overline{\mathrm{x}}=11.2\end{array}$ & $\mathrm{n}$ & $\begin{array}{l}\mathrm{E}_{30}, \mathrm{~mm} \\
\overline{\mathrm{x}}=26.5\end{array}$ & $\mathrm{n}$ & $\begin{array}{l}\mathrm{pH} \\
\bar{x}=6.65\end{array}$ \\
\hline $6-30$ & 88 & $-4.7 \pm 0.6$ & 92 & $6.6 \pm 1.3$ & 92 & $-0.086 \pm 0.008$ \\
\hline $31-60$ & 101 & $-2.7 \pm 0.6$ & 106 & $2.1 \pm 1.3$ & 106 & $-0.025 \pm 0.008$ \\
\hline $61-90$ & 98 & $-1.8 \pm 0.6$ & 104 & $2.1 \pm 1.3$ & 104 & $-0.015 \pm 0.008$ \\
\hline $91-120$ & 117 & $-1.6 \pm 0.6$ & 125 & $-0.2 \pm 1.2$ & 125 & $-0.009 \pm 0.008$ \\
\hline $121-150$ & 136 & $-0.5 \pm 0.5$ & 143 & $-0.1 \pm 1.2$ & 143 & $-0.006 \pm 0.007$ \\
\hline $151-180$ & 119 & $-1.0 \pm 0.6$ & 129 & $-0.4 \pm 1.2$ & 128 & $-0.009 \pm 0.007$ \\
\hline $181-210$ & 135 & $0.2 \pm 0.5$ & 145 & $-1.6 \pm 1.1$ & 145 & $0.008 \pm 0.007$ \\
\hline $211-240$ & 168 & 0 & 178 & 0 & 178 & 0 \\
\hline $241-270$ & 122 & $-1.4 \pm 0.5$ & 127 & $2.0 \pm 1.2$ & 127 & $0.000 \pm 0.007$ \\
\hline $271-300$ & 103 & $-0.7 \pm 0.6$ & 115 & $-0.0 \pm 1.2$ & 115 & $0.005 \pm 0.008$ \\
\hline$>300$ & 132 & $-1.6 \pm 0.5$ & 144 & $2.4 \pm 1.2$ & 144 & $0.025 \pm 0.007$ \\
\hline$P$-value & & $<0.001$ & & $<0.001$ & & $<0.001$ \\
\hline
\end{tabular}

${ }^{1}$ Milk coagulation traits: $\mathrm{R}=$ milk renneting time $(\mathrm{min}), \mathrm{E}_{30}=$ curd firmness $(\mathrm{mm})$.

$(\geq 0.20)$ as that for the 305 -d fat yield (Table 5). In addition, estimates of heritability for the milk coagulation traits and for protein content were higher than the herd effects for these traits. For the other 305-d production traits, the herd effects were higher than the estimates of heritability.

\section{DISCUSSION}

\section{Differences Between Breeds in Milk Coagulation Ability}

Holstein-Friesian cows were superior to FA cows in average MCA as well as in the proportion of NC milk and PC milk. However, the first HOL cows producing NC milk in Finland were detected. Difference in the prevalence of NC and PC milk seemed to be one of the reasons for breed differences in MCA between HOL and FA. In addition, $\kappa$-casein B-allele, which is known to have a favorable effect on MCA (e.g., Ikonen et al., 1999a; Lenoir et al., 2000), is more common in HOL than in FA (Ikonen, 2000).

In our study, the number of daughters per sire was low (1 to 33). However, in the group of FA sires with
10 or more daughters, the proportion of NC daughters clearly varied, indicating genetic origin of $\mathrm{NC}$ milk. The same has also been observed in the previous studies in FA (Ikonen et al., 1999a, 2004). Interestingly, HOL cows that produced NC milk were related to each other, which may be an indication of genetic factors causing this phenomenon in HOL as well. However, the Italian (Zannoni et al., 1981; Mariani et al., 1982; Malossini et al., 1996) and Canadian studies (Okigbo et al., 1985a, $1985 b)$ did not elaborate on the possible genetic cause of NC milk.

\section{Effects of Lactation Stage and Parity on the Studied Traits}

According to most of the other studies (e.g., Mariani et al., 1982; Ostersen et al., 1997; Kübarsepp et al., 2003; Tyrisevä et al., 2003; Ikonen et al., 2004), MCA was best at the beginning and at the end of lactation, and $\mathrm{pH}$ of milk was lowest at the very beginning of the lactation (e.g., Ostersen et al., 1997; Tyrisevä et al., 2003; Ikonen et al., 2004), which might be associated with the good coagulation properties of the early lacta-

Table 5. The estimates of variance components, ${ }^{1}$ herd effect $\left(\mathrm{c}^{2}\right)$ and heritabilities $\left(\mathrm{h}^{2}\right)$ with their standard errors (se) for the milk coagulation traits, ${ }^{2} \mathrm{pH}$ and $305-\mathrm{d}$ milk production traits.

\begin{tabular}{|c|c|c|c|c|c|}
\hline Variable & $\sigma_{\mathrm{a}}^{2}$ & $\sigma_{\mathrm{c}}^{2}$ & $\sigma_{\mathrm{e}}^{2}$ & $c^{2} \pm s e$ & $\mathrm{~h}^{2} \pm \mathrm{se}$ \\
\hline $\mathrm{R}, \min$ & 4.689 & 1.334 & 16.274 & $0.06 \pm 0.01$ & $0.21 \pm 0.05$ \\
\hline $\mathrm{E}_{30}, \mathrm{~mm}$ & 25.363 & 10.479 & 77.846 & $0.09 \pm 0.02$ & $0.22 \pm 0.05$ \\
\hline $\mathrm{pH}$ & 0.001 & 0.001 & 0.003 & $0.11 \pm 0.02$ & $0.18 \pm 0.05$ \\
\hline Milk yield, kg & 304332 & 1009667 & 795249 & $0.48 \pm 0.03$ & $0.14 \pm 0.04$ \\
\hline Fat yield, kg & 1105 & 1801 & 1480 & $0.41 \pm 0.03$ & $0.25 \pm 0.04$ \\
\hline Fat $\%$ & 0.058 & 0.173 & 0.132 & $0.48 \pm 0.03$ & $0.16 \pm 0.04$ \\
\hline Protein yield, kg & 298 & 1288 & 708 & $0.56 \pm 0.03$ & $0.13 \pm 0.03$ \\
\hline Protein \% & 0.015 & 0.010 & 0.022 & $0.21 \pm 0.03$ & $0.32 \pm 0.05$ \\
\hline
\end{tabular}

${ }^{1} \sigma_{\mathrm{a}}^{2}=$ Additive genetic variance, $\sigma_{\mathrm{c}}^{2}=$ herd variance, $\sigma_{\mathrm{e}}^{2}=$ residual variance.

${ }^{2}$ Milk coagulation traits: $\mathrm{R}=$ milk renneting time $(\mathrm{min}), \mathrm{E}_{30}=$ curd firmness $(\mathrm{mm})$. 
Table 6. Comparison of the 10 highest and the 10 lowest herds based on the 305 -d protein yields for various characteristics ${ }^{1}$ in the region of the Lammi cooperative dairy.

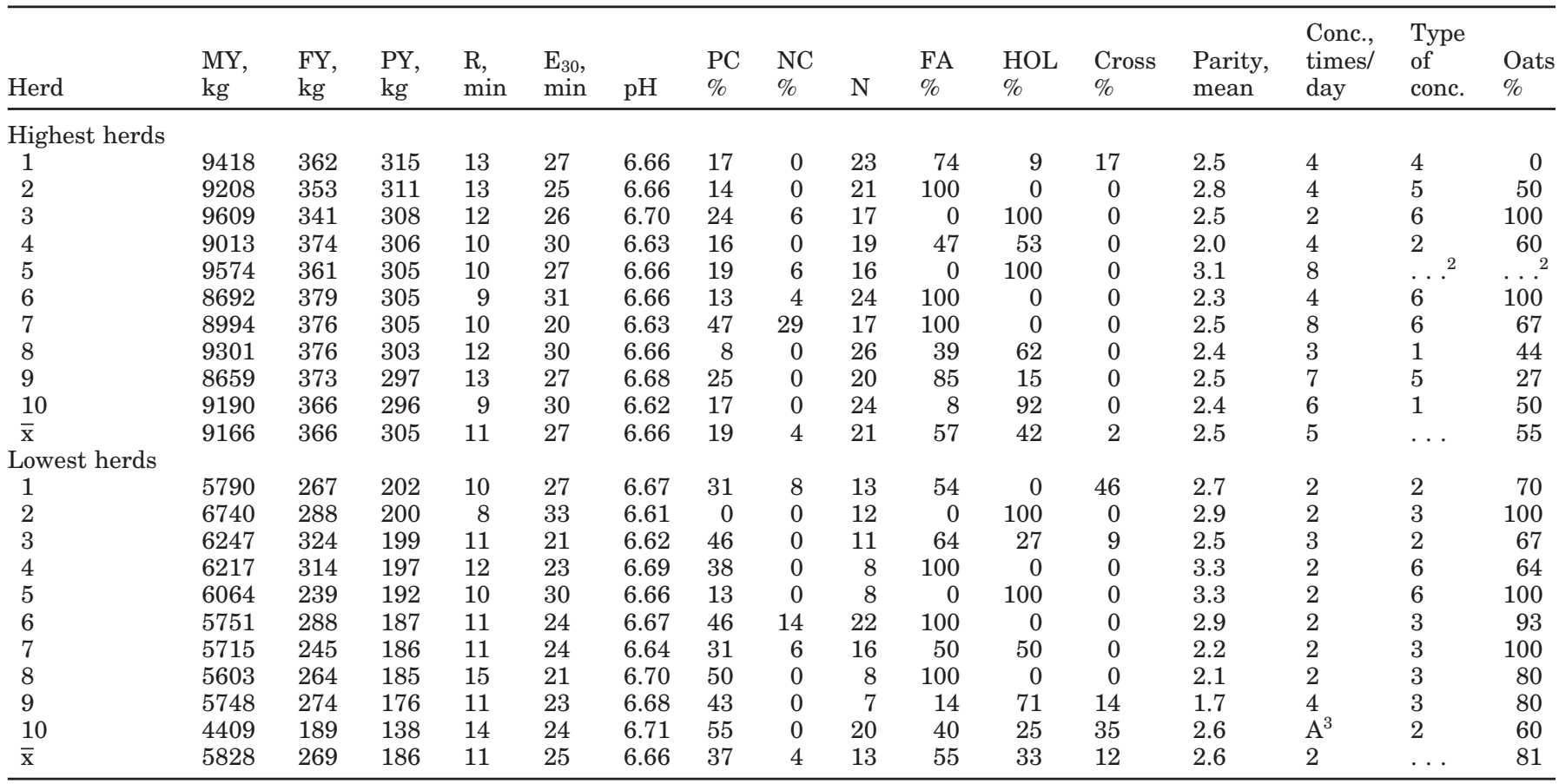

${ }^{1} \mathrm{MY}=305-\mathrm{d}$ milk yield $(\mathrm{kg}), \mathrm{FY}=305-\mathrm{d}$ fat yield $(\mathrm{kg}), \mathrm{PY}=305-\mathrm{d}$ protein yield $(\mathrm{kg}), \mathrm{R}=$ Milk renneting time (min), $\mathrm{E}_{30}=\mathrm{curd}$ firmness $(\mathrm{mm}), \mathrm{PC} \%=$ proportion of poorly coagulated $\left(\mathrm{E}_{30}<20 \mathrm{~mm}\right)$ milk samples, $\mathrm{NC} \%=$ proportion of non-coagulated milk samples, $\mathrm{N}=$ number of cows, FA $\%$ = proportion of Finnish Ayrshire cows, HOL\% = proportion of Holstein-Friesian cows, Cross $\%=$ proportion of crossbred cows. A mean $\mathrm{PC} \%$, NC\%, FA\%, HOL\%, and Cross \% were calculated as a mean of the records of the individual cows of the herds. Conc., times/ day $=$ feeding frequency of concentrate, Type of conc. $=$ type of concentrate (see Materials), Oats $\%=$ proportion of oats in the farm mixture.

${ }^{2}$ No information available.

${ }^{3}$ Automatic feeding device.

tion milk. In addition, based on the study by Ostersen et al. (1997), calcium content of milk is highest at the beginning and at the end of lactation, which may, in part, explain the good MCA of the early and late lactation milks.

In our study, the proportion of NC milk samples did not vary along lactation in FA. In the other Finnish studies (Tyrisevä et al., 2003; Ikonen et al., 2004), and in one Estonian study (Kübarsepp et al., 2003), NC milk samples have been most common in midlactation. Moreover, in our study, all the NC milk samples in HOL cows were observed in late lactation. This was in agreement with the studies by Okigbo et al. (1985a, 1985b), in which the production of NC milk in Canadian Holstein cows was most common in late lactation. Unlike in the present study, poor MCA in late lactation was associated with the very high $\mathrm{pH}$ of milk in the studies by Okigbo et al. (1985a, 1985b). Also in the study by Mariani et al. (1982) in Italian Friesian, noncoagulation of milk was more common in mid or late lactation than in early lactation.

In the literature, effects of parity on MCA are contradictory. As in our study, parity had no effect on MCA in the study by Ikonen et al. (1999a). In the study by Ikonen et al. (2004), primiparous cows were worse for MCA than the other cows. This difference was associated with the noncoagulation of milk, which was more common in primiparous cows than in the other cows. In our study, no variation in the prevalence of $\mathrm{NC}$ milk along parity was observed. Contrary to above studies, in the studies by Lindström et al. (1984) and Tyrisevä et al. (2003), MCA deteriorated with parity.

\section{Effect of Herd}

Herd explained only a minor part of the variation in MCA compared with that in 305-d milk production traits. These results were in agreement with the results reported by Ikonen et al. (2004).

The positive influence of more frequent feeding of concentrate was evident for 305-d milk production traits in our study. Frequent feeding of concentrate also had a favorable effect on MCA, especially on the proportion of the PC samples. However, it was not associated with the proportion of NC milk samples. These results were distinguished when the effects of feeding 
frequency of concentrate were considered, as well as when the highest and lowest producing herds were compared.

The concentrate feeding frequency may be associated with the energy status of the cows, even though results in the literature have been contradictory. Based on some feeding experiments, higher feeding frequency has increased milk, protein, and/or fat yields (e.g., Yang and Varga, 1989; Robinson and McNiven, 1994; Shabi et al., 1999). The authors explained the results with the greater intake of total DM (Robinson and MacNiven, 1994), with the reduced fluctuation of rumen ammonia concentration (Yang and Varga, 1989), and with the increased postruminal digestion of $\mathrm{CP}$ and nonstructural carbohydrates (Shabi et al., 1999). On the other hand, in some studies higher feeding frequency had no positive response on milk production traits (e.g., Macleod et al., 1993). Based on Macleod et al. (1993), one explanation of contradictory results might be the interaction between the concentrate and forage type, their ratio in the diet, and the level of milk production.

Macheboeuf et al. (1993) and Malossini et al. (1996) have observed a favorable effect of the high energy level of the diet on MCA. In the study by O'Brien et al. (1997), there was a tendency of favorable association between high daily herbage allowance and good MCA, even if the results were not statistically significant. In addition, in the study by Ostersen et al. (1997), energy status of the cows at calving affected MCA of the cows during the entire lactation, cows with the good energy status being associated with the good MCA. Further, Malossini et al. (1996) observed, in accordance with the results of our study that the proportion of PC samples decreased as the energy level of the diet increased. This was not, however, associated with NC milk.

In our study, as the level of oats increased in the farm mixture, 305-d milk production traits decreased, and MCA slightly deteriorated. Results might be associated with the lower energy value of oats compared with barley.

It can be assumed in field data that concentrate feeding frequency and type of concentrate also illustrate the level of farm input. It is possible that the most professional farms feed their animals more frequently and use the combination of farm mixture and compound feed more often than the more traditional farms. However, the proportion of the records in the classes of type of concentrate was about equal in the classes of concentrate feeding frequency, indicating that the 2 effects were not confounded.

\section{Estimates of Heritability}

The estimate of heritability for curd firmness in our study (0.22) was somewhat lower than those for Finnish
Ayrshire (0.39, Ikonen et al., 2004) and for Italian Friesian $(0.40$, curd firmness as a classified trait, Bittante et al., 2002). The estimates of heritability for the 305-d milk production traits were also lower than the corresponding estimates in the literature (e.g., Welper and Freeman, 1992; Van Dorp et al., 1998; Ikonen et al., 1999b).

\section{CONCLUSIONS}

Holstein-Friesian cows were superior to Finnish Ayrshire cows in milk coagulation ability. This was due, in part, to the differences in the prevalence of noncoagulating milk. Herd explained only a minor part of the variation in milk coagulation ability. The frequent feeding of the concentrate was associated with good milk coagulating ability as well as for the high milk, protein, and fat yields.

\section{ACKNOWLEDGMENTS}

We thank Sakari Juurus, Ari Mäkelä, and Kaisa Tyrni in Lammi cooperative dairy and the herdsmen in the region of the dairy for providing the data, and Taina Malmsten and Sari Morri for conducting the laboratory analyses, and Veijo Vilva for helping in technical details with the software. This research project was partly financed by Ministry of Agriculture and Forestry, Finland.

\section{REFERENCES}

Bergère, J. L., and J. Lenoir. 2000. Cheese manufacturing accidents and cheese defects. Pages 447-508 in Cheesemaking from Science to Quality Assurance. 2nd rev. ed. A. Eck and J.-C. Gillis, ed. Lavoisier Publishing, Paris, France.

Bittante, G., M. Marusi, F. Cesarini, M. Povinelli, and M. Cassandro. 2002. Genetic analysis on milk rennet-coagulation ability in Italian Holstein cows. Proc. 7th World Congr. Genet. Appl. Livest. Prod., Montpellier, France. CD-ROM communication no 09-03.

Brulé, G., J. Lenoir, and R. Remeuf. 2000. The casein micelle and milk coagulation. Pages 7-40 in Cheesemaking From Science to Quality Assurance. 2nd rev. ed. A. Eck and J.-C. Gillis, ed. Lavoisier Publishing, Paris, France.

Finnish Food and Drink Industries' Federation. 2003. URL: http:// etl.fi/

Green, M. L., and A. S. Grandison. 1993. Secondary (non-enzymatic) phase of rennet coagulation and post-coagulation phenomena. Pages 101-140 in Cheese: Chemistry, Physics, and Microbiology. Vol. 1. 2nd ed. P. F. Fox, ed. Chapman and Hall, London, UK.

Groeneveld, E. 1990. PEST user's manual. Institute of Animal Husbandry and Animal Behaviour, Federal Agricultural Research Centre, Germany.

Groeneveld, E. 1997. VCE4 user's guide and reference manual. Institute of Animal Husbandry and Animal Behaviour, Federal Agricultural Research Centre, Germany.

Ikonen, T. 2000. Possibilities of genetic improvement of milk coagulation properties of dairy cows. Ph.D. Diss., Univ. Helsinki, Helsinki, Finland. Available: http://ethesis.helsinki.fi/julkaisut/maa/ kotie/vk/ikonen/

Ikonen, T., K. Ahlfors, R., Kempe, M. Ojala, and O. Ruottinen. 1999a. Genetic parameters for the milk coagulation properties and prev- 
alence of noncoagulating milk in Finnish dairy cows. J. Dairy Sci. 82:205-214.

Ikonen, T., S. Morri, A.-M. Tyrisevä, O. Ruottinen, and M. Ojala. 2004. Genetic and phenotypic correlations between milk coagulation properties, milk production traits, somatic cell count, casein content, and pH of milk. J. Dairy Sci. 87:458-467.

Ikonen, T., M. Ojala, and O. Ruottinen. 1999b. Associations between milk protein polymorphism and first lactation milk production traits in Finnish Ayrshire cows. J. Dairy Sci. 82:1026-1033.

Ikonen, T., O. Ruottinen, E.-L., Syväoja, K. Saarinen, E. Pahkala, and M. Ojala. 1999c. Effect of milk coagulation properties of herd bulk milks on yield and composition of Emmental cheese. Agric. Food Sci. Fin. 8:411-422.

Kübarsepp, I., M. Henno, K. Mihhejev, and O. Kärt. 2003. Milk coagulation properties of dairy cattle breeds raised in Estonia and factors influencing it. Page 90 in Proc. 22th Nordic Assoc. Agric. Sci. Congr., Turku, Finland.

Lenoir, J., F. Remuef, and N. Schneid. 2000. Rennetability of milk. Pages 213-238 in Cheesemaking from Science to Quality Assurance. 2nd rev. ed. A. Eck and J.-C. Gillis, eds. Lavoisier Publishing, Paris, France.

Lindström, U. B., V. Antila, and J. Syväjärvi. 1984. A note on some genetic and non-genetic factors affecting clotting time of Ayrshire milk. Acta Agric. Scand. 34:349-355.

Macheboeuf, D., J.-B. Coulon, and P. D'Hour. 1993. Effect of breed, protein genetic variants and feeding on cows' milk coagulation properties. J. Dairy Res. 60:43-54.

Macleod, G. K., P. E. Colucci, A. D. Moore, D. G. Grieve, and N. Lewis. 1994. The effects of feeding frequency of concentrates and feeding sequence of hay on eating behavior, ruminal environment and milk production in dairy cows. Can. J. Anim. Sci. 74:103-113.

Malossini, F., S. Bovolenta, C. Poras, M. Dalla Rosa, and W. Ventura. 1996. Effect of diet and breed on milk composition and rennet coagulation properties. Ann. Zootech. 45:29-40.

Mariani, P., M. Pecorari, and E. Fossa. 1982. Le caratteristiche di coagulazione del latte in rapporto allo stadio della lattazione ed ai livelli di produzione. [Rennet-coagulation of milk in relation to lactation stage and yield levels of cows]. Sci. Tecn. Latt. Cas. 33:409-425.

O'Brien, B., J. J. Murphy, J. F. Connolly, R. Mehra, T. P. Guinee, and G. Stakelum. 1997. Effect of altering the daily herbage allow- ance in mid lactation on the composition and processing characteristics of bovine milk. J. Dairy Res. 64:621--626.

Okigbo, L. M., G. H. Richardson, R. J. Brown, and C. A. Ernstrom. 1985a. Effects of $\mathrm{pH}$, calcium chloride, and chymosin concentration on coagulation properties of abnormal and normal milk. J. Dairy Sci. 68:2527-2533.

Okigbo, L. M., G. H. Richardson, R. J. Brown, and C. A. Ernstrom. 1985b. Variation in coagulation properties of milk from individual cows. J. Dairy Sci. 68:822-828.

Ostersen, S., J. Foldager, and J. E. Hermansen. 1997. Effects of stage of lactation, milk protein genotype and body condition at calving on protein composition and renneting properties of bovine milk. J. Dairy Res. 64:207-219.

Robinson, P. H., and M. A. McNiven. 1994. Influence of flame roasting and feeding frequency of barley on performance of dairy cows. J. Dairy Sci. 77:3631-3643.

Sala, G., I. De Noni, and L. Pellegrino. 1993. Caratteristiche chimicoanalitiche di latti a lenta coagulazione presamica. [Chemical and analytical properties of milk with poor rennet clotting aptitude]. Sci. Tecn. Latt. Cas. 44:292--308.

Shabi, Z., I. Bruckental, S. Zamwell, H. Tagari, and A. Arieli. 1999. Effects of extrusion of grain and feeding frequency on rumen fermentation, nutrient digestibility, and milk yield and composition in dairy cows. J. Dairy Sci. 82:1252-1260.

Tervala, H.-L., V. Antila, and J. Syväjärvi. 1985. Factors affecting the renneting properties of milk. Meijeritieteellinen Aikakauskirja XLIII 1:16-25.

Tyrisevä, A.-M., T. Ikonen, and M. Ojala. 2003. Repeatability estimates for milk coagulation traits and non-coagulation of milk in Finnish Ayrshire cows. J. Dairy Res. 70:91-98.

Van Dorp, T. E., J. C. M. Dekkers, S. W. Martin, and J. P. T. M. Noordhuizen. 1998. Genetic parameters of health disorders, and relationships with 305-day milk yield and conformation traits of registered Holstein cows. J. Dairy Sci. 81:2264-2270.

Welper, R. D., and A. E. Freeman. 1992. Genetic parameters for yield traits of Holsteins, including lactose and somatic cell score. J. Dairy Sci. 75:1342-1348.

Yang, C.-M. J., and G. A. Varga. 1989. Effect of three concentrate feeding frequencies on rumen protozoa, rumen digesta kinetics, and milk yield in dairy cows. J. Dairy Sci. 72:950-957.

Zannoni, M., M. Mongardi, and S. Annibaldi. 1981. Standardization of the renneting ability of milk by formagraph. Note II: Data processing. Sci. Tecn. Latt. Cas. 32:153-164. 